\title{
Microbial respiration in the asteroid diffusive boundary layer influenced sea star wasting disease during the 2013-2014 northeast Pacific Ocean mass mortality event
}

\author{
Ian Hewson* \\ Department of Microbiology, 215 Wing Hall, Cornell University, Ithaca, NY 14853, USA
}

\begin{abstract}
Sea star wasting disease (SSWD) describes a suite of abnormal signs in affected Asteroidea (Echinodermata). The disease gained prominence in 2013-2014 after it was linked to mass mortality in the northeast Pacific Ocean. Recent work highlighted the key role of heterotrophic microorganisms inhabiting the diffusive boundary layer around sea stars in generating disease signs via oxygen depletion. However, it is unclear whether this phenomenon occurred during the 2013-2014 mass mortality or how surviving populations may have adapted to low oxygen conditions. In this opinion piece, I outline evidence for this phenomenon in both oceanographic conditions experienced by asteroids in 2013-2014 and from population genetic studies of surviving asteroids.
\end{abstract}

KEY WORDS: Sea star wasting disease $\cdot$ Diffusive boundary layer $\cdot$ Oxygen $\cdot$ Hypoxia

\section{INTRODUCTION}

Sea star wasting disease (SSWD) describes an abnormal condition affecting $>20$ species to varying intensity, resulting in tissue damage and, in some cases, mass mortality (Hewson et al. 2014, Menge et al. 2016, Miner et al. 2018). SSWD is defined by gross signs which include limb curling, loss of turgor, limb autotomy, and epidermal/body wall lesions (through which organs may protrude). Lesions form as a result of inflammation (coelomocyte infiltration) around ossicles and mutable collagenous tissues of the body wall, which results in epidermal edema and ulceration (Work et al. 2021). While initially attributed to the sea star associated densovirus (Asteroid ambi-

\footnotetext{
${ }^{*}$ Corresponding author: hewson@cornell.edu
}

densovirus 1; Hewson et al. 2014), subsequent study found densoviruses generally to be normal constituents of asteroid viromes (Hewson et al. 2018, Jackson et al. 2020a,b), and viruses became more prominent in virome surveys comparing SSWDaffected and grossly normal specimens (Hewson et al. 2020). SSWD is associated with monotonic (Bates et al. 2009, Eisenlord et al. 2016, Kohl et al. 2016) and periodic (Aalto et al. 2020) elevated water temperatures and, conversely, lower water temperatures (Menge et al. 2016) at some sites. It is unclear whether SSWD has a single etiology or is a constellation of conditions with the same disease signs since asteroids possess a limited repertoire of grossly observed stress responses (Hewson et al. 2018, 2019).

() The author 2021. Open Access under Creative Commons by Attribution Licence. Use, distribution and reproduction are unrestricted. Authors and original publication must be credited. 
Recent work has identified the key role of microorganisms inhabiting the asteroid-water interface following a model known as boundary layer oxygen diffusion limitation (BLODL, Aquino et al. 2021; Fig. 1). In this model, elevated dissolved organic matter (DOM) may stimulate heterotrophic microbial growth, reducing dissolved oxygen concentrations $\left(\left[\mathrm{O}_{2}\right]\right)$ within the thin layer of water that adheres to asteroid surfaces (i.e. the boundary layer) and likely resulting in a cascade of deleterious ef-

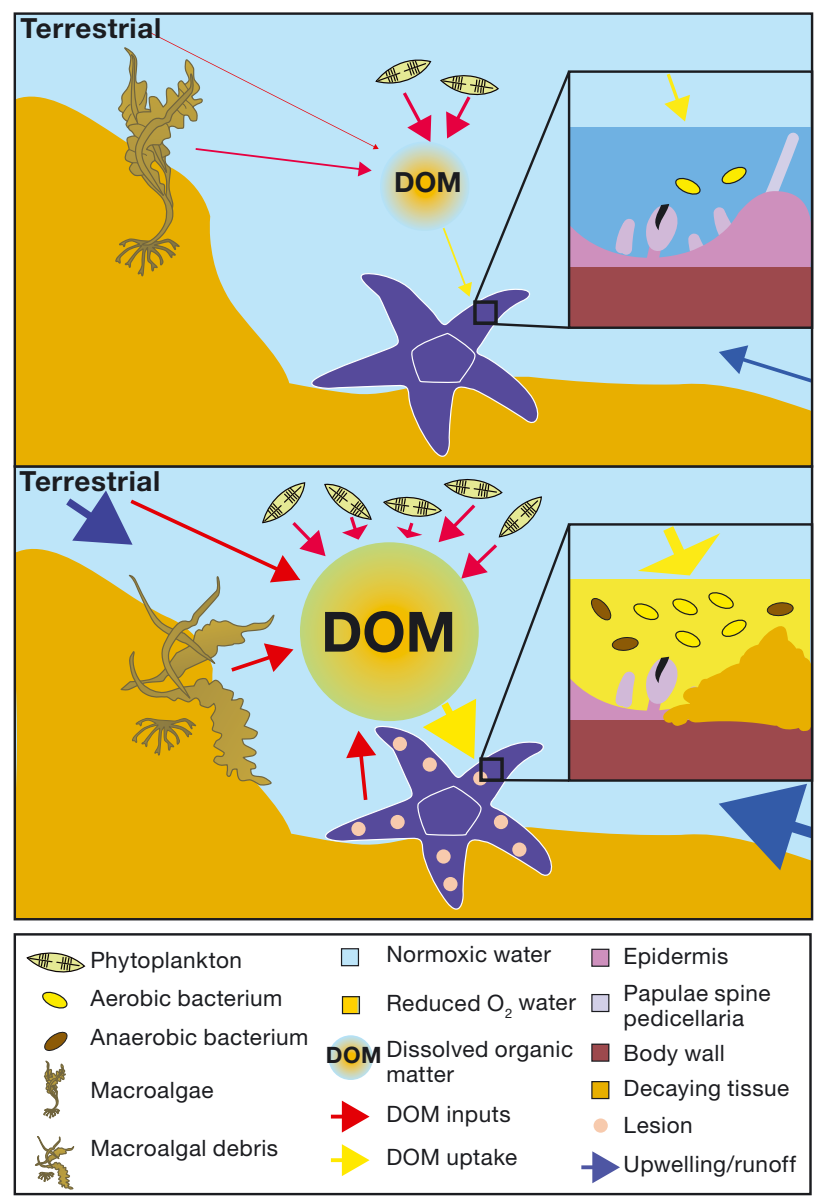

Fig. 1. Conceptual diagram of hypothesized triggers for boundary layer oxygen diffusion limitation (BLODL) under (top panel) typical conditions and (bottom panel) elevated productivity. Under typical conditions, primary production from phytoplankton and macroalgae generate dissolved organic matter (DOM), and some DOM originates from terrestrial sources. Upwelling or terrestrial inputs may stimulate primary production which in turn elevates DOM concentrations. DOM may also arise from macroalgal debris. In turn, this DOM is remineralized by heterotrophic bacteria within the diffusive boundary layer around asteroids, leading to suboxic stress in tissues and lesion formation. Decaying sea stars may themselves release DOM, further fueling BLODL in nearby asteroids. Elevated water temperatures (e.g. in summer) may further exacerbate BLODL due to stimulated remineralization rates by heterotrophic bacteria fects to host tissues. Aquino et al. (2021) provided clues to 2 potential DOM sources: (1) phytoplankton-derived DOM and (2) the presence of decaying tissues presumably leaching DOM into surrounding waters. However, there remain important questions about whether the mass mortality in 2013-2014 was related to this etiology, what environmental conditions may have led to the abrupt mass mortality in 2013-2014 and not in years prior or since, and whether BLODL may reflect in the population genetics of surviving asteroids and their progeny. In this opinion piece, I summarize knowledge on $\mathrm{O}_{2}$ sensitivity of asteroids in the context of BLODL, explore evidence for the primary productivity-BLODL relationship during 2013-2014, and examine genomic and genetic evidence for suboxic conditions affecting asteroids. I conclude with recommendations for future research.

\section{ASTEROID $\mathrm{O}_{2}$ SENSITIVITY}

Aquino et al. (2021) provided evidence for anaerobic metabolism among microorganisms inhabiting the asteroid diffusive boundary layer preceding the onset or during wasting progression and observed SSWD under experimentally depleted $\left[\mathrm{O}_{2}\right]$. Surface seawater, especially in coastal zones, is typically saturated with dissolved $\mathrm{O}_{2}$ due to atmospheric diffusion and wave activity. Hence, most bacteria and archaea in coastal plankton have aerobic metabolisms (DeLong 1992, Suzuki et al. 2001, Gifford et al. 2014). However, spatially localized depleted $\left[\mathrm{O}_{2}\right]$ (i.e. 'microzones') may occur near surfaces experiencing limited hydrodynamic flow (Gregg et al. 2013). These microzones may be exacerbated by an external supply of DOM. Within organic-matter-rich particles in the water column e.g. zooplankton fecal pellets and marine snow (Alldredge \& Cohen 1987), $\left[\mathrm{O}_{2}\right]$ may fall to hypoxic levels within $50 \mu \mathrm{m}$ of the particle surface. On metazoan surfaces (for example, scleractinian corals), $\left[\mathrm{O}_{2}\right]$ may be depleted both at the water-polyp interface, the coral-algal interface, within digitate coral colonies, and at the entire reef interface, especially at night (reviewed in Nelson \& Altieri 2019). Within intertidal habitats, turbulent water motion may break down diffusive boundary layers. Indeed, cilia on scleractinian coral surfaces create vortices within diffusive boundary layers; however, $\mathrm{O}_{2}$ depletion is greater in active cilia vs. arrested cilia, presumably due to greater respiration by ciliated cells (Pacherres et al. 2020). Microbial biofilms are found in a variety of intertidal habitats 
where they resist periodic desiccation and light stress (Decho 2000). The speed with which depleted $\left[\mathrm{O}_{2}\right]$ manifest within the boundary layer on aquatic surfaces upon immersion has not been investigated. Photosynthetic microbial mats, which are oxic $5 \mathrm{~mm}$ from their surface in the light, experience hypoxia $\left(<20 \% \mathrm{O}_{2}\right.$ saturation) in this layer within $30 \mathrm{~min}$ of being placed in the dark (Epping et al. 1999). Hence, it is possible that periodic cycles of emersion in $\mathrm{O}_{2}$-rich conditions and immersion and subsequent development of depleted $\left[\mathrm{O}_{2}\right]$ within diffusive boundary layers may occur rapidly and persist for the period of immersion. While direct measurements of $\mathrm{O}_{2}$ saturation at the asteroid-water interface have not been made, $\left[\mathrm{O}_{2}\right]$ may deplete well away from asteroid surfaces (see Fig. 1 for an example in Pisaster ochraceus).

SSWD may be related to seasonal or episodic variation in primary production. At a field site in the Salish Sea, Aquino et al. (2021) reported correspondence between patterns of chlorophyll a ( $\mathrm{chl}$ a) decline, frequent low $\left[\mathrm{O}_{2}\right]$ events and overall depleted $\left[\mathrm{O}_{2}\right]$, and SSWD. Phytoplankton excrete $2-50 \%$ of their photosynthetic yield daily as DOM (reviewed in Thornton 2014), which forms an important nutritional source for bacterioplankton in the microbial loop (Azam et al. 1983). Excess phytoplankton-fueled bacterial respiration, caused by eutrophication and enrichment from terrestrial sources and within upwelling zones, may result in 'dead zones' (e.g. Mississippi River Plume, Peruvian upwelling zone, Benguela current; reviewed in Diaz \& Rosenberg 2008). These, in turn, may be exacerbated by seasonal temperature changes (Murphy et al. 2011) and restricted bathymetry (Diaz 2001). Under typical oceanographic conditions, DOM supply does not result in depleted $\left[\mathrm{O}_{2}\right]$ in bulk seawater since atmospheric diffusion exceeds respiration. However, suboxic microzones may occur within aggregates (Shanks \& Reeder 1993) and within colonial cyanobacterial colonies (Roe et al. 2012) in saturated water column $\left[\mathrm{O}_{2}\right]$. Hence, measurements of $\left[\mathrm{O}_{2}\right]$ in the water column may not adequately address the spatial scales on which organisms respire through passive diffusion, since these likely occur within $\mu \mathrm{m}$ to $\mathrm{mm}$ above animal surfaces (Fig. 2; Gregg et al. 2013).

The mechanisms by which asteroids are particularly sensitive to ambient dissolved $\mathrm{O}_{2}$ are not well constrained by empirical studies. Water column hypoxia events were not observed in concert with SSWD in 2013 and beyond. Asteroids mostly rely on passive respiration (cf. ventilation) and gas diffusion across outer membranes to meet respiratory demand, a point illustrated by mass mortality events of benthic invertebrates, including asteroids, correlated with low $\left[\mathrm{O}_{2}\right.$ ] (reviewed in Diaz \& Rosenberg 1995, Levin 2003, Levin et al. 2009). Hypoxia impairs immune responses to wounds in Asterias rubrens, increasing coelomocyte counts in coelomic fluid and inhibiting the translocation of apoptosis-protecting heat shock protein 70 from coelomocyte cytoplasm to nucleus (Holm et al. 2008). Differentiation of coelomocytes from the coelomic epithelium is also affected by $\mathrm{Mn}^{2+}$ released in anaerobic environments (Oweson et al. 2010). Hence, there is likely a direct impact of depleted $\left[\mathrm{O}_{2}\right]$ on the ability of asteroids to control infiltrates and opportunistic pathogens or prevent apoptosis triggered by damage or other environmental stimuli.

\section{BLODL AND THE 2013-2014 MASS MORTALITY}

The coherence of SSWD with primary production in the Salish Sea (Aquino et al. 2021) raises the question of why SSWD mass mortality in the northeast Pacific occurred in the 12 mo period following June 2013, especially when asteroids normally persist at sites experiencing very high phytoplankton biomass. Suchy et al. (2019) observed a prolonged (10 mo) period of decreased water column stratification concomitant with strong predominately southerly winds in Autumn 2013 and Spring 2014 in the northern Strait of Georgia. Chl a concentrations in the region were also higher in late 2013 compared to the previous 8 yr (Suchy et al. 2019) and the 1981-2010 average (Moore et al. 2014) and was marked by a significant peak in late August (later than previous years; Moore et al. 2014). Mean monthly precipitation was anomalously lower in mid-summer compared to 2005-2012 means, with no rainfall in July, but then increased dramatically ( $200 \%$ of annual mean) in late September 2013 prior to the SSWD onset in October (Hewson et al. 2018). The summer drought affecting the Salish Sea region in Summer 2013 and its abrupt end in the fall may have delivered significant DOM and other nutrients into coastal waters, which may have in turn stimulated BLODL both directly and through stimulated primary production.

The discontinuous latitudinal emergence of SSWD in 2013-2014 and regional apparent longshore sequence of SSWD occurrence (Hewson et al. 2014) is consistent with phytoplankton bloom extent. The spatial scale of phytoplankton blooms 


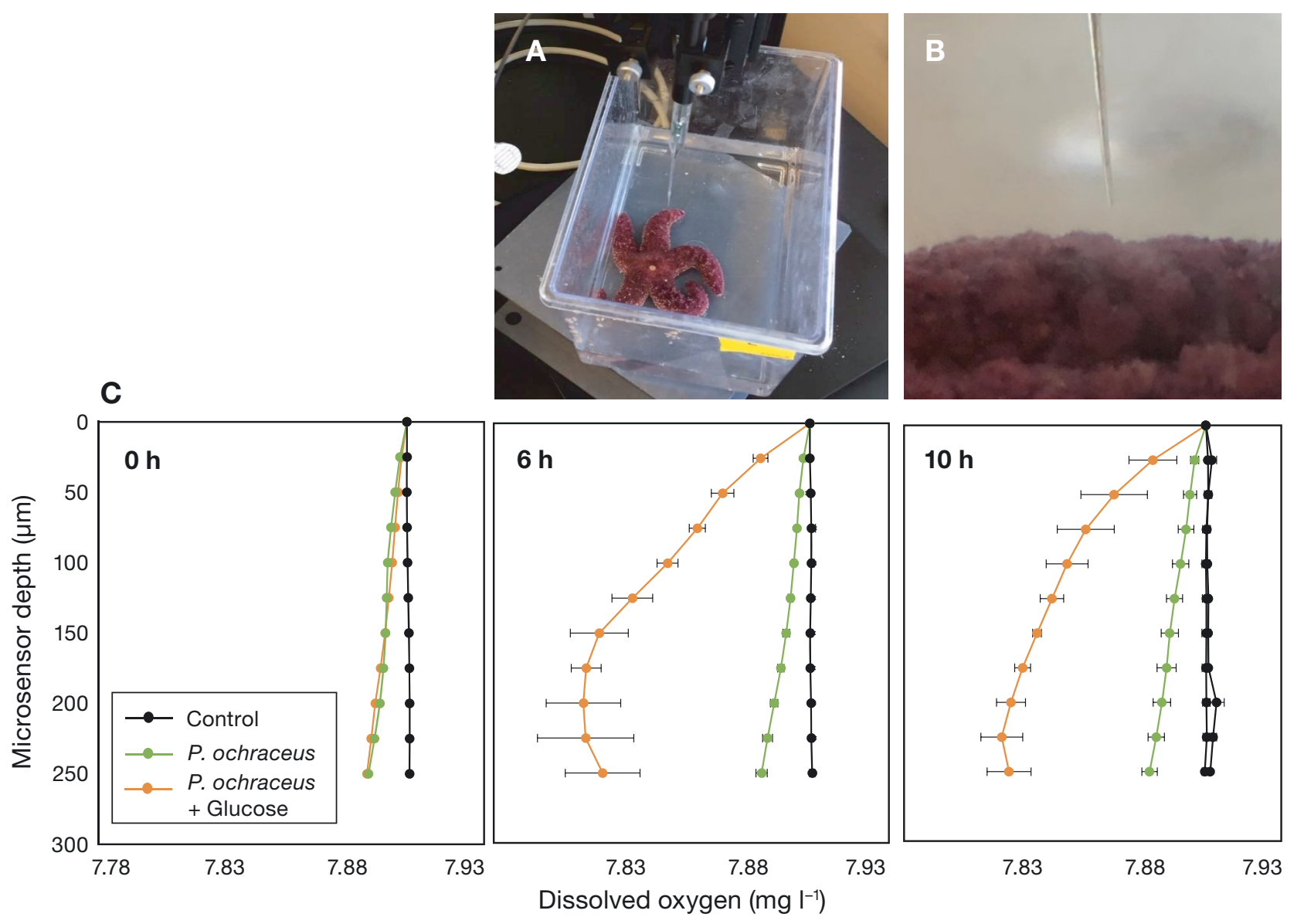

Fig. 2. Example of $\mathrm{O}_{2}$ depletion near the surface of Pisaster ochraceus. (A,B) Oxygen was measured using microelectrodes, which are fragile and easily damaged by animal movement. (C) The vertical profiles of dissolved $\mathrm{O}_{2}$ were measured at $0 \mathrm{~h}$ (left), $6 \mathrm{~h}$ (middle), and $10 \mathrm{~h}$ (right) in 2 specimens and in the water column away from specimens. One specimen was enriched with $10 \mu \mathrm{M}$ glucose for comparison. The bottom of each vertical profile is within $\sim 1000 \mu \mathrm{m}$ of the specimen surface. These profiles illustrate that $\mathrm{O}_{2}$ depletion can occur within $\mu \mathrm{m}$ to $\mathrm{mm}$ of asteroid surfaces, albeit the depletion of dissolved oxygen concentration with glucose enrichment $(\sim 2 \%)$ likely underestimates values in the field since the specimen was in a shallow dish at the time

sustained solely by terrestrial runoff and groundwater discharge ranges from $880-3600 \mathrm{~km}^{2}$ in the Southern California Bight (Santoro et al. 2010). Assuming these blooms are constrained within $10 \mathrm{~km}$ of shore, the areal extent of phytoplankton-derived DOM inputs is well within the reported longshore spread of SSWD (Hewson et al. 2014). Upwelling, on the other hand, may affect wider coastal productivity patterns. In 2013, strong upwelling was recorded between $36^{\circ}$ and $48^{\circ} \mathrm{N}$ (i.e. $1332 \mathrm{~km}$ ) (Leising 2014), which corresponds with the SSWDaffected geographic range. Consultation of Pacific Fisheries Environmental Laboratory upwelling indices (Columbia River DART 2021) revealed that cumulative upwelling at the time of wasting departed the 2007-2016 mean at affected sites (Fig. 3). Since coastal upwelling brings inorganic nutrients from deep waters to euphotic waters, elevated upwelling may lead to enhanced primary productivity and, consequently, enhanced DOM release. Additionally, upwelling may fuel harmful algal blooms (e.g. those producing toxins) which may cause additional stress to asteroids. For example, mass mortality of echinoderms (asteroids and echinoids) along a $100 \mathrm{~km}$ stretch of coastline near Bodega Bay, California, was attributed to an algal toxin (Jurgens et al. 2015).

Another potential source of DOM fueling BLODL is macroalgal detritus (Krumhansl \& Scheibling 2012) and exudates (Abdullah \& Fredriksen 2004). Macroalgae experience seasonal increases in biomass during spring and fall due to elevated temperature and elevated nutrient conditions, but may also experience nutrient limitation in summer (Brown et al. 

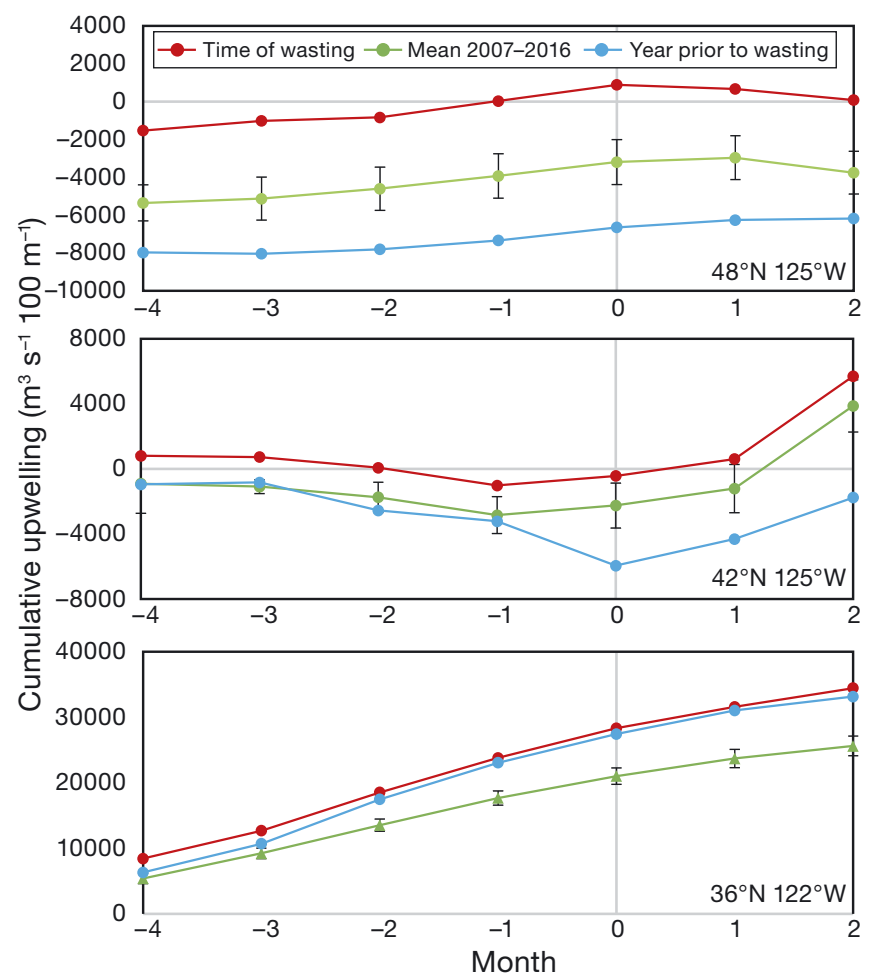

Fig. 3. Comparison of cumulative upwelling indices prior to wasting (Months -4 to -1 ), at the time of wasting (Month 0 ), and after wasting onset (Months 1 and 2) compared to the 2007-2016 mean and the year prior to wasting at 3 latitudes. Error bars: \pm SE. The 3 locations are (top) west of La Push, Washington; (middle) west of the Oregon/California Border; and (bottom) west of San Luis Obispo, California. Data on sea star wasting onset (Month 0) at each site determined from Hewson et al. (2014). Upwelling indices accessed at Columbia River DART (2021)

1997). Laminaria hyperborea has a pronounced seasonal productivity cycle in the North Atlantic Ocean, including an active growing season from February through May during which previous year lamina are shed, followed by a non-growing season until November (Kain 1979). Exudation of DOM is greatest during L. hyperborea's non-growing season (Abdullah \& Fredriksen 2004). SSWD peaked during the presumed period of greatest DOM exudation in the Northeast Pacific. Both macroalgal detritus (Robinson et al. 1982) and exuded DOM (Zhang \& Wang 2017) are highly labile and rapidly assimilated by bacteria and so may have contributed to BLODL. While there have been no studies of seasonal exudation or detrital release in the regions affected by SSWD, the seasonal variation of SSWD and coherence with DOM production and detrital breakdown (Krumhansl \& Scheibling 2012) warrants further investigation.

\section{EVIDENCE OF BLODL FROM THE GENETIC MAKEUP OF SURVIVING POPULATIONS AND THEIR TRANSCRIPTIONAL PROFILES}

Selection for individuals that maintain fitness under amplified DOM availability may be reflected in genetic changes in survivors and progeny. In a metatranscriptomic study comparing gene expression between SSWD-affected and grossly normal individuals, the relative transcription of high affinity cytochrome $C$ oxidase (ccb3) was higher in SSWD-affected than grossly normal specimens (Gudenkauf \& Hewson 2015). Transcription of ccb3 is highly responsive to anoxic conditions in Pseudomonas aeruginosa (Kawakami et al. 2010) and plays a key role in biofilm formation under anoxic stress (Hamada et al. 2014). Cytochrome P450 2J6, which plays a dual role in both oxidation and detoxification of $\mathrm{H}_{2} \mathrm{~S}$ (Tobler et al. 2014), was expressed in at least 2 studies of SSWDaffected asteroids (Fuess et al. 2015, Gudenkauf \& Hewson 2015). Hence, transcriptional signals in both asteroids and their microbiomes suggest depleted $\left[\mathrm{O}_{2}\right]$ conditions within tissues at the time of mass mortality (Gudenkauf \& Hewson 2015) and during challenge experiments (Fuess et al. 2015).

Surviving juvenile recruits are genetically distinct from asteroids before 2013 (Schiebelhut et al. 2018). Loci selected for in surviving populations correspond to those heightened in experiments with elevated temperature (Ruiz-Ramos et al. 2020). In particular, Ruiz-Ramos et al. (2020) found a synchronous decrease in expression of NADH dehydrogenase 5 (ND5) among field SSWD-affected specimens and those subjected to temperature challenge in aquaria and corresponding mutation in ND5 in surviving populations. Extracellular hypoxia causes downregulation of NADH dehydrogenase in vertebrate cells (Piruat \& López-Barneo 2005), and variation in mitochondrial ND5 genes is related to hypoxia sensitivity in humans (Sharma et al. 2019). These results may suggest that asteroids affected by wasting and their progeny have some indication of response to depleted $\left[\mathrm{O}_{2}\right]$, and future work is recommended to examine the transcriptional impacts of low $\left[\mathrm{O}_{2}\right]$ to determine whether differentially expressed genes match those under selection since the 2013-2014 mass mortality. Attention in future work should focus on mitochondrial respiratory gene transcription patterns in control specimens, since many of the genetic changes and expressed genes noted in this section may also reflect hypoxic conditions imparted by inhibition of cellular respiration (cf. extracellular hypoxia). 


\section{FUTURE RESEARCH RECOMMENDATIONS}

There is clearly still much to be learned about the etiology of SSWD. Histopathologic and gross comparisons between asteroids that develop wasting signs in experimental challenge and those that experience hypoxia in the field may help elucidate the role of $\mathrm{O}_{2}$ in wasting etiology. Direct measurements of both $\left[\mathrm{O}_{2}\right]$ at the animal-water interface and over time as well as the bacterial activity within this layer will aid in understanding whether microbial activity results in significant depletion of $\left[\mathrm{O}_{2}\right]$. A useful approach to measure near-animal $\left[\mathrm{O}_{2}\right]$ using color radiometric planar optode imaging was presented by Larsen et al. (2011). Direct measurement of bacterial production in surface layers through e.g. radioisotopic approaches (Fuhrman \& Azam 1982, Kirchman et al. 1985) may aid in understanding heterotrophic growth rates. Finally, since bacterial proliferation on animal surfaces may be accompanied by the production of secreted enzymes that irritate animal surfaces, it is recommended that future work examine the secretome (de O Santos et al. 2011) of bacteria inhabiting the animal-water interface.

Acknowledgements. The author is grateful to Chris DeRito and Esther Angert for microelectrode analyses performed on Pisaster ochraceus. The author also thanks Citlalli Aquino, Ryan Besemer, Jordan Rede, John Wares, Peter Raimondi, Lauren Schiebelhut, Ian Porter, and Jed Sparks for assistance in reviewing an early manuscript draft. This work was supported by National Science Foundation Grant OCE1737127 awarded to I.H.

\section{LITERATURE CITED}

Aalto EA, Lafferty KD, Sokolow SH, Grewelle RE and others (2020) Models with environmental drivers offer a plausible mechanism for the rapid spread of infectious disease outbreaks in marine organisms. Sci Rep 10:5975

Abdullah MI, Fredriksen S (2004) Production, respiration and exudation of dissolved organic matter by the kelp Laminaria hyperborea along the west coast of Norway. J Mar Biol Assoc UK 84:887-894

Alldredge AL, Cohen Y (1987) Can microscale chemical patches persist in the sea? Microelectrode study of marine snow, fecal pellets. Science 235:689

* Aquino CA, Besemer RM, DeRito CM, Kocian J and others (2021) Evidence that microorganisms at the animalwater interface drive sea star wasting disease. Front Microbiol 11:610009

Azam F, Fenchel T, Field JG, Gray JS, Meyerreil LA, Thingstad F (1983) The ecological role of water-column microbes in the sea. Mar Ecol Prog Ser 10:257-263

Bates AE, Hilton BJ, Harley CDG (2009) Effects of temperature, season and locality on wasting disease in the keystone predatory sea star Pisaster ochraceus. Dis Aquat Org 86:245-251
Brown MT, Nyman MA, Keogh JA, Chin NKM (1997) Seasonal growth of the giant kelp Macrocystis pyrifera in New Zealand. Mar Biol 129:417-424

Columbia River DART (Data Access in Real Time) (2021) Pacific Ocean coastal upwelling index graphics \& text. www.cbr.washington.edu/dart/query/upwell_graph_text

de O Santos E, Alves N Jr, Dias GM, Mazotto AM and others (2011) Genomic and proteomic analyses of the coral pathogen Vibrio coralliilyticus reveal a diverse virulence repertoire. ISME J 5:1471-1483

Decho AW (2000) Microbial biofilms in intertidal systems: an overview. Cont Shelf Res 20:1257-1273

* DeLong EF (1992) Archaea in coastal marine environments. Proc Natl Acad Sci USA 89:5685-5689

*Diaz RJ (2001) Overview of hypoxia around the world. J Environ Qual 30:275-281

Diaz RJ, Rosenberg R (1995) Marine benthic hypoxia: a review of its ecological effects and the behavioural responses of benthic macrofauna. Oceanogr Mar Biol Annu Rev 33:245-303

*Diaz RJ, Rosenberg R (2008) Spreading dead zones and consequences for marine ecosystems. Science 321: 926-929

Eisenlord ME, Groner ML, Yoshioka RM, Elliott J and others (2016) Ochre star mortality during the 2014 wasting disease epizootic: role of population size structure and temperature. Philos Trans R Soc B 371:20150212

*epping EHG, Khalili A, Thar R (1999) Photosynthesis and the dynamics of oxygen consumption in a microbial mat as calculated from transient oxygen microprofiles. Limnol Oceanogr 44:1936-1948

Fuess LE, Eisenlord ME, Closek CJ, Tracy AM and others (2015) Up in arms: immune and nervous system response to sea star wasting disease. PLOS ONE 10:e0133053

* Fuhrman JA, Azam F (1982) Thymidine incorporation as a measure of heterotrophic bacterioplankton production in marine surface waters: evaluation and field results. Mar Biol 66:109

*Gifford SM, Sharma S, Moran MA (2014) Linking activity and function to ecosystem dynamics in a coastal bacterioplankton community. Front Microbiol 5:185

*Gregg AK, Hatay M, Haas AF, Robinett NL and others (2013) Biological oxygen demand optode analysis of coral reef-associated microbial communities exposed to algal exudates. PeerJ 1:e107

*Gudenkauf BM, Hewson I (2015) Metatranscriptomic analysis of Pycnopodia helianthoides (Asteroidea) affected by sea star wasting disease. PLOS ONE 10:e0128150

Hamada M, Toyofuku M, Miyano T, Nomura N (2014) cbb3type cytochrome $c$ oxidases, aerobic respiratory enzymes, impact the anaerobic life of Pseudomonas aeruginosa PAO1. J Bacteriol 196:3881-3889

* Hewson I, Button JB, Gudenkauf BM, Miner B and others (2014) Densovirus associated with sea-star wasting disease and mass mortality. Proc Natl Acad Sci USA 111: 17278-17283

*Hewson I, Bistolas KSI, Quijano Carde EM, Button JB and others (2018) Investigating the complex association between viral ecology, environment and Northeast Pacific sea star wasting. Front Mar Sci 5:77

Hewson I, Sullivan B, Jackson EW, Xu Q and others (2019) Perspective: Something old, something new? Review of wasting and other mortality in Asteroidea (Echinodermata). Front Mar Sci 6:406

*Hewson I, Aquino CA, deRito CM (2020) Virome variation 
during sea star wasting disease progression in Pisaster ochraceus (Asteroidea, Echinodermata). Viruses 12:1332

Holm K, Hernroth B, Thorndyke M (2008) Coelomocyte numbers and expression of HSP70 in wounded sea stars during hypoxia. Cell Tissue Res 334:319-325

Jackson EW, Pepe-Ranney C, Johnson MR, Distel DL, Hewson I (2020a) A highly prevalent and pervasive densovirus discovered among sea stars from the North American Atlantic coast. Appl Environ Microbiol 86: e02723-19

Jackson EW, Wilhelm RC, Johnson MR, Lutz HL and others (2020b) Diversity of sea star-associated densoviruses and transcribed endogenized viral elements of densovirus origin. J Virol 95:e01594-20

Jurgens LJ, Rogers-Bennett L, Raimondi PT, Schiebelhut LM, Dawson MN, Grosberg RK, Gaylord B (2015) Patterns of mass mortality among rocky shore invertebrates across $100 \mathrm{~km}$ of Northeastern Pacific coastline. PLOS ONE 10: e0126280

Kain J (1979) A view of the genus Laminaria. Oceanogr Mar Biol Annu Rev 17:101-161

Kawakami T, Kuroki M, Ishii M, Igarashi Y, Arai H (2010) Differential expression of multiple terminal oxidases for aerobic respiration in Pseudomonas aeruginosa. Environ Microbiol 12:1399-1412

Kirchman D, Knees E, Hodson R (1985) Leucine incorporation and its potential as a measure of protein synthesis by bacteria in natural aquatic systems. Appl Environ Microbiol 49:599-607

Kohl WT, McClure TI, Miner BG (2016) Decreased temperature facilitates short-term sea star wasting disease survival in the keystone intertidal sea star Pisaster ochraceus. PLOS ONE 11:e0153670

Krumhansl KA, Scheibling RE (2012) Production and fate of kelp detritus. Mar Ecol Prog Ser 467:281-302

Larsen M, Borisov SM, Grunwald B, Klimant I, Glud RN (2011) A simple and inexpensive high resolution color ratiometric planar optode imaging approach: application to oxygen and $\mathrm{pH}$ sensing. Limnol Oceanogr Methods 9:348-360

Leising AW, Schroeder ID, Bograd SJ, Bjorkstedt EO (2014) State of the Caliofornia Current 2013-2014: El Niño looming. CalCOFI Rep 55:51-87

Levin LA (2003) Oxygen minimum zone benthos: adaptation and community response to hypoxia. Oceanogr Mar Biol Annu Rev 41:1-45

Levin LA, Ekau W, Gooday AJ, Jorissen F and others (2009) Effects of natural and human-induced hypoxia on coastal benthos. Biogeosciences 6:2063-2098

Menge BA, Cerny-Chipman EB, Johnson A, Sullivan J, Gravem S, Chan F (2016) Sea star wasting disease in the keystone predator Pisaster ochraceus in Oregon: insights into differential population impacts, recovery, predation rate, and temperature effects from long-term research. PLOS ONE 11:e0153994

* Miner CM, Burnaford JL, Ambrose RF, Antrim L and others (2018) Large-scale impacts of sea star wasting disease (SSWD) on intertidal sea stars and implications for recovery. PLOS ONE 13:e0192870

Moore SK, Stark K, Bos J, Williams P, Newton J, Dzinbal K (eds) (2014) Puget sound marine waters: 2013 overview. Puget Sound Ecosystem Monitoring Program Marine Waters Workgroup, Seattle, WA

Murphy RR, Kemp WM, Ball WP (2011) Long-term trends in

Editorial responsibility: Inna Sokolova,

Rostock, Germany

Reviewed by: K. Ritchie, C. Mah and 1 anonymous referee
Chesapeake Bay seasonal hypoxia, stratification, and nutrient loading. Estuaries Coasts 34:1293-1309

Nelson HR, Altieri AH (2019) Oxygen: the universal currency on coral reefs. Coral Reefs 38:177-198

* Oweson C, Li C, Söderhäll I, Hernroth B (2010) Effects of manganese and hypoxia on coelomocyte renewal in the echinoderm, Asterias rubens (L.). Aquat Toxicol 100: 84-90

* Pacherres CO, Ahmerkamp S, Schmidt-Grieb GM, Holtappels M, Richter C (2020) Ciliary vortex flows and oxygen dynamics in the coral boundary layer. Sci Rep 10:7541

* Piruat JI, López-Barneo J (2005) Oxygen tension regulates mitochondrial DNA-encoded complex I gene expression. J Biol Chem 280:42676-42684

Kobinson JD, Mann KH, Novitsky JA (1982) Conversion of the particulate fraction of seaweed detritus to bacterial biomass. Limnol Oceanogr 27:1072-1079

Koe KL, Barbeau K, Mann EL, Haygood MG (2012) Acquisition of iron by Trichodesmium and associated bacteria in culture. Environ Microbiol 14:1681-1695

Ruiz-Ramos DV, Schiebelhut LM, Hoff KJ, Wares JP, Dawson MN (2020) An initial comparative genomic autopsy of wasting disease in sea stars. Mol Ecol 29:1087-1102

* Santoro AE, Nidzieko NJ, van Dijken GL, Arrigo KR, Boehma AB (2010) Contrasting spring and summer phytoplankton dynamics in the nearshore Southern California Bight. Limnol Oceanogr 55:264-278

* Schiebelhut LM, Puritz JB, Dawson MN (2018) Decimation by sea star wasting disease and rapid genetic change in a keystone species, Pisaster ochraceus. Proc Natl Acad Sci USA 115:7069-7074

* Shanks AL, Reeder ML (1993) Reducing microzones and sulfide production in marine snow. Mar Ecol Prog Ser 96: 43-47

* Sharma S, Singh S, Gupta R, Ganju L, Singh S, Kumar B, Singh Y (2019) Mitochondrial DNA sequencing reveals association of variants and haplogroup M33a2'3 with high altitude pulmonary edema susceptibility in Indian male lowlanders. Sci Rep 9:10975

* Suchy KD, Le Baron N, Hilborn A, Perry RI, Costa M (2019) Influence of environmental drivers on spatio-temporal dynamics of satellite-derived chlorophyll $a$ in the Strait of Georgia. Prog Oceanogr 176:102134

Suzuki MT, Beja O, Taylor LT, DeLong EF (2001) Phylogenetic analysis of ribosomal RNA operons from uncultivated coastal marine bacterioplankton. Environ Microbiol 3:323-331

* Thornton DCO (2014) Dissolved organic matter (DOM) release by phytoplankton in the contemporary and future ocean. Eur J Phycol 49:20-46

Tobler M, Henpita C, Bassett B, Kelley JL, Shaw JH (2014) $\mathrm{H}_{2} \mathrm{~S}$ exposure elicits differential expression of candidate genes in fish adapted to sulfidic and non-sulfidic environments. Comp Biochem Physiol A Mol Integr Physiol $175: 7-14$

Work TM, Weatherby TM, DeRito CM, Besemer RM, Hewson I (2021) Pathology of experimental sea star wasting disease in Pisaster ochraceus shows a basal-to-surface process affecting color phenotypes differently. Dis Aquat Org 145:121-33

K Zhang T, Wang X (2017) Release and microbial degradation of dissolved organic matter (DOM) from the macroalgae Ulva prolifera. Mar Pollut Bull 125:192-198

Submitted: January 29, 2021

Accepted: April 21, 2021

Proofs received from author(s): June 11, 2021 